\title{
The Role of Gender in Preparedness and Response Behaviors towards Flood Risk in Serbia
}

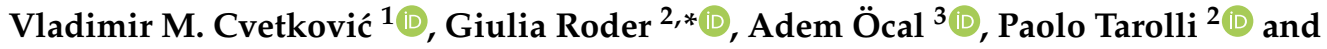 \\ Slavoljub Dragićević 4 (D) \\ 1 Faculty of Security Studies, University of Belgrade, Gospodara Vučića 50, 11040 Belgrade, Serbia; \\ vmc@fb.bg.ac.rs \\ 2 Department of Land, Environment, Agriculture and Forestry, University of Padova, Agripolis, \\ viale dell' Università 16, 35020 Legnaro, Italy; paolo.tarolli@unipd.it \\ 3 Independent Researcher, 06500 Ankara, Turkey; ocadem@gmail.com \\ 4 Faculty of Geography, University of Belgrade, Studentski Trg 3/III, 11000 Belgrade, Serbia; sasa@gef.bg.ac.rs \\ * Correspondence: giulia.roder@phd.unipd.it; Tel.: +39-(049)-8272700
}

Received: 18 September 2018; Accepted: 3 December 2018; Published: 6 December 2018

\begin{abstract}
Adverse outcomes from 2014 flooding in Serbia indicated problematic response phase management accentuated by a gender imbalance. For this reason, we investigated the risk perceptions and preparedness of women and men regarding these types of events in Serbia. Face-to-face interviews, administered to 2500 participants, were conducted across 19 of 191 municipalities. In light of the current findings, men seemed to be more confident in their abilities to cope with flooding, perceiving greater individual and household preparedness. By contrast, women displayed a deeper understanding of these events. Perhaps owing to a deeper level of understanding, women demonstrated more household-caring attitudes and behaviors and were more prone to report a willingness to help flood victims at reception centers. Emergency management agencies and land planners should account for these differences in gender awareness and preparedness. Based on these findings, doing so may increase citizen participation and shared responsibility under flood hazard scenarios.
\end{abstract}

Keywords: flood risk; perception; preparedness; gender; Serbia

\section{Introduction}

Gender disparities exert powerful differences within societies worldwide, even in the field of disasters. Women and men are not merely at risk because of their location in time and place [1] but because of a complex mix of influential factors that include "differentiated roles and responsibilities, skills and capabilities, vulnerabilities, social relations, institutional structures, and long-standing traditions and attitudes" [2]. These social forces are thought to shape different behavioral tendencies, including those related to the ability to anticipate, prepare for, respond to, and recover from disasters [3]. The interest and recognition of different attitudes and behaviors among men and women in the wake of environmental problems have origins in the 1990s [4-7]. However, the assessment of gender differences at all levels of the disaster cycle has historically been less than satisfactory. The social research on disasters has often been approached from a mostly gender-blind perspective, mindful of some basic findings reported in the literature for years (e.g., women are more at risk for psychosocial reactions [8]). According to the gender glossary, gender blindness is "the failure to recognize that gender is an essential determinant of social outcomes impacting on projects and policies". This social-cognitive bias can influence disaster management actions in place, affecting both physical actions and psychosocial preparedness and response [9]. 
As stated above, increased interest in gender inclusion in the disaster context occurred during the International Decade for Natural Disaster Reduction (1990-1999); however gender-specific guidelines were missing. In 2000, the special session of the UN General Assembly, "Gender equality, development and peace for the twenty-first century" highlighted the inefficiencies and inadequacies of existing approaches in responding to disasters [10]. Thus, the need for explicitly incorporating considerations on gender into disaster prevention, mitigation, and recovery strategies has been increasingly emphasized. The latest Sendai Framework for Disaster Risk Reduction signed off by 187 Member States on 18 March 2015 in Japan, and lead-up discussions and platforms discussed this topic more assiduously, which included a request to increase the empowerment and participation of women (and youth) [11]. The rising importance of gender-sensitive research was underlined by the United Nations Office for Disaster Risk Reduction, defined as one of the objectives for the period 2015-2020.

As a consequence, one can conclude that during the last century, progressive change regarding this issue increasingly became a current concern for the disaster management community. One emphasis is the effort devoted to understanding social power relations regarding disaster and emergency management. In particular, as promoted through UN processes, mainstreaming the role of gender includes an increased focus on integrating women in disaster policy, practice, and research.

In countries like Serbia, the context for the current study, analyzing gender differences is of particular importance. For example, during a major 2014 flood event, women were found to be particularly affected as they were weakly represented in the flood-planning response and overall decision-making processes [12]. For example, women argued that information did not reach them adequately, thus exposing gaps in risk communication. Many women's organizations responded immediately and offered assistance in the most vulnerable areas. However, the public perception and media promulgated the idea that men were the first to react. In a policy context, the importance of protection and rescue from floods from a gender perspective has also been recognized by the Council for Gender Equality Government of the Republic of Serbia. In fact, on 29 May 2014, the council held an extraordinary meeting dedicated to this specific issue, concluding that developing more gender-sensitive statistics, indicators of vulnerability, reconstruction, and recovery was a necessary initial step. Thus, for both research- and policy-driven reasons, we conducted extensive interviews to explore and underline the differences in risk perception, preparedness, and response behaviors of both women and men in the wake of flood events in Serbia to foster increasingly targeted solutions for disaster planning and management.

\subsection{Literature Review}

Research into risk perception aims to understand the cognitive and emotional processes and behavioral choices of individuals or groups in risk-related contexts [13]. Behaviors that people enact before, during, and after disasters are the first and most critical support for the management of emergency circumstances and can contribute to the minimization of adverse effects. According to Slovic et al. [14] and Griffin et al. [15], risk encompasses an affective component responsible for two different perceptions: risk as a feeling and as a rational conception. Thus, risk is not only a combination of perceived probability but also and the feeling of worry related to it [16]. According to Cutter et al. [17], "as men and women view the world differently, it follows that they also perceive risks differently". Gender differences may be linked to different cultural and societal contexts and dynamics. In this regard, being able to spend time watching TV or fraternizing in community centers to access hazard information [18] as well as work in the tobacco fields in Indonesia [19] gave men a greater awareness to promote responsive behavior. Female counterparts, confined to child-care and housekeeping responsibilities, as well as those watching less television and therefore receiving less knowledge of such events as a result of less interaction outside the domestic sphere, were put in jeopardy at the onset of a hazard occurrence [18-20]. By contrast, during Hurricane Andrew, women were largely responsible for preparing family members and expressed a higher knowledge of stocking provisions and getting the household ready for the hurricane [21]. Similar findings have been highlighted by De Marchi et al. [22]. Such findings point to emergency management messaging 
that understands more localized contexts and can capitalize on household tendencies, leveraging the respective gender-specific tendencies to be able to complement each other more effectively. The form of concern expressed so far can be related to the perceived likelihood of occurrence with personal consequences [23], which could affect the psychological balance [24]. Accordingly, in a recent work on Icelandic volcanic hazards regarding air travel [25], the perceptions of the necessity of restrictions were positively associated with the perceived risk of an accident and were lower for those who were more concerned about the consequences of false alarms or who had personally experienced travel disruption; they were also higher for women than men. O'Neill et al. found females to be more worried about potential flooding, and regarding perceived exposure to flood risk, gender was not found to be statistically significant [16].

Before a disaster, research shows that many individuals perceive their own risk as sufficiently low, reflecting an 'it will not happen to me' set of beliefs. As a result, people do not feel the need to invest voluntarily in protective measures such as strengthening their house or buying insurance [26]. Risk perceptions differently drive the willingness to protect and take action before a disaster occurs. Risk awareness is not merely a perception of hazard occurrence or the feeling of threat at the individual or household level, but also a 'behavioral tendency'. Thus, it is related to the interest and intentions to manage more or less intensively a hazard situation. Several researchers have reported men's higher confidence in their proactive behaviors during an emergency, rating their level of self-preparedness as significantly high [24,27-29]. This behavior may at least in part be driven by the social role that men usually play within the family context. By contrast, among the Wujie indigenous people interviewed in Taiwan, it was statistically determined that women felt more prepared than men when thinking about possible future hazards [30]. Similarly, women undertook more hazard adjustments than men in a US study [31]. Among these actions, there is a range of essential amenities and supplies that are helpful for the first period in a post-disaster phase. Baker [32] found that being prepared meant having additional items in the house that were essential, particularly in the response and early recovery process. According to the results obtained by Able and Nelson [33], men may see themselves as responsible for some of the necessary supplies that are needed to survive in the wake of disasters. However, in the USA, less than half of the individuals reported having a household emergency plan, including household instructions for safer locations in the case of an emergency [34].

Regarding one aspect of planning, the few studies determining gender differences have found that women are more likely to evacuate than men, perhaps because of socially constructed gender roles and dynamics [35]. Enarson [36] found that mothers rarely resisted evacuation orders, treating them more seriously than men, who may be more likely to disregard such orders. Delegating trust to local authorities and their preventive actions could magnify or shrink the response of a community by displaying a high willingness to adopt protection measures [37] in the first case, or demonstrating dramatically low preparedness in the second [30,38,39].

Official rescue attempts are made by emergency rescue services and, inevitably, those contained within relevant government authorities, supplemented by volunteer organizations [40,41]. Provision of more informal forms of voluntary assistance depends on the social order, personal characteristics, attitudes, and situational variables [42]. Assisting during and after a natural disaster can significantly contribute to reducing the consequences of disasters. Proper assistance, coming from an informed public, can create an environment where the management of a disaster event is more likely to be successful [43]. Every individual has the right to be informed of the potential risks and preparedness measures that can implement to enable secure and efficient actions [44]. Results suggest that providing specific information on how preparedness measures can be realized may increase the confidence of women in their ability to protect their property $[45,46]$.

Thus, the findings to date support the idea that gender roles within the household and community may have direct implications for the successful prevention, mitigation, and management of hazard situations. Moderating social and demographic factors such as age, education, income, and marital status can also play a role gender-wise. As a simple example, one's economic status enables a better 
absorption and recovery from losses. Perhaps less obvious is the finding that women have been found to have a higher sensitivity to possible monetary losses [47,48]. However, having adequate resources does not on its own ensure that women are not exposed to stress, anxiety, and concern about evacuation and losses, job security, or the health, safety, and well-being of family and friends [49]. Poorly maintained and inadequate infrastructures are typical of low-income women. At particular risk are single-mothers, who also tend to have lower economic means and educational levels [50,51]. Single parents typically have the same worries as two-parent households but have added responsibilities for protecting and preparing the family for an emergency. This solo status can be easily unnoticed in the recovery process [52]. Two-parent families are typically better placed, both financially and psychologically. However, even in these types of families, there can be considerable gender disparity. For example, in Kenya, $29 \%$ of the women interviewed had no formal education and $77.5 \%$ depending on their husband's income to survive [53]. On the other hand, living in a community with a considerable proportion of highly educated women increases personal disaster preparedness and provides easier access to and seeking out of disaster-related information [54].

\subsection{Flood Risk in Serbia}

Floods are the most common natural hazard risks in Serbia $[55,56]$. Their frequency, intensity, and location across the territory make them a continuous threat to the ecological equilibrium and the social and economic development [57]. The potentially floodable area, considered for a return period of 100 years, covers an area of 16,000 km² (Figure 1), where 500 large settlements, 515 industrial assets, $680 \mathrm{~km}$ of railroads and approximately $4000 \mathrm{~km}$ of roads are at risk [58].

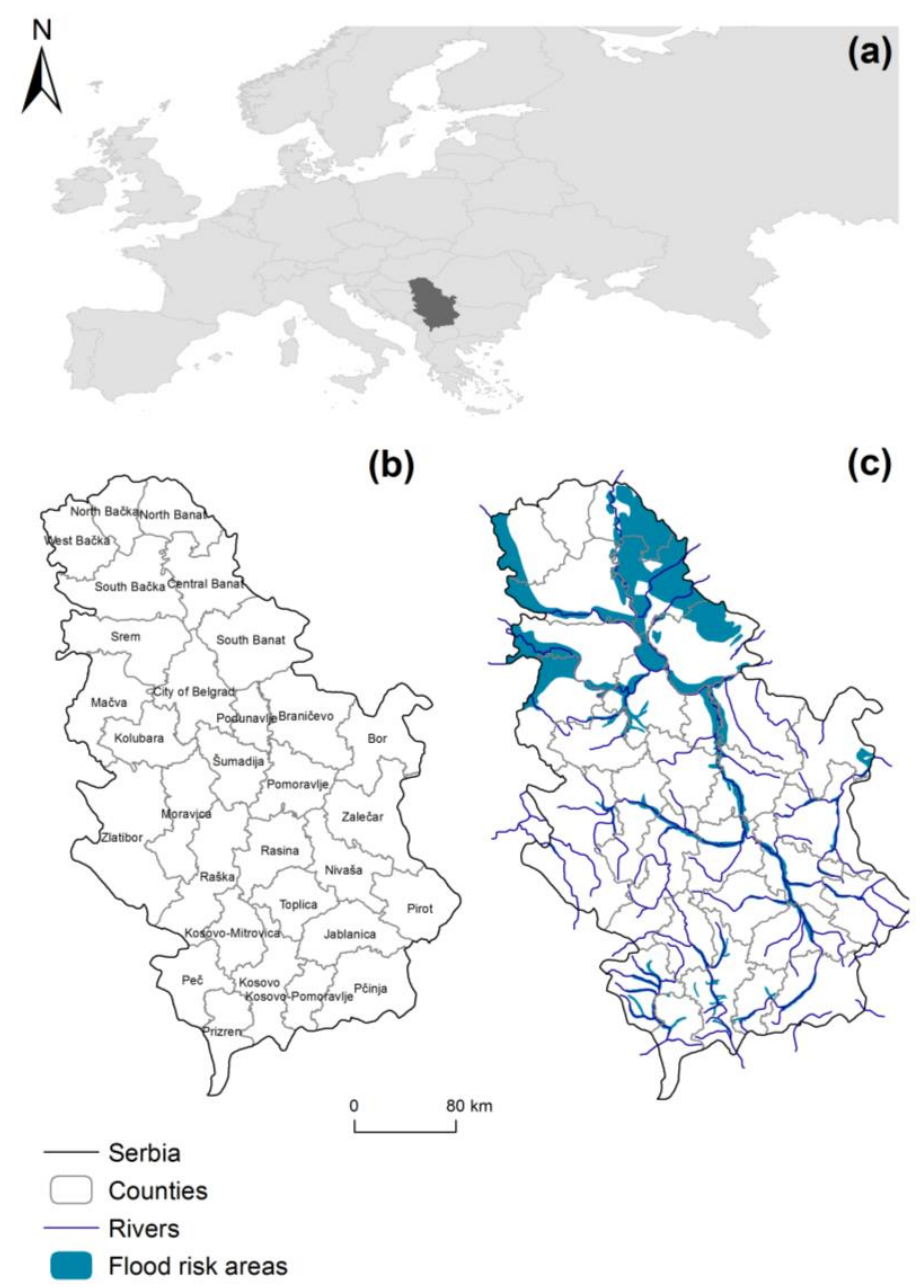

Figure 1. (a) Location of Serbia; (b) counties of Serbia; (c) flood prone areas with 100-year return period. 
The most vulnerable area is the northern part of Serbia, in the main river catchment of the country where the Danube River is located. The degree of vulnerability of the population and its properties are not uniform, but vary depending on the type of natural disaster and expected potential damage [55,59].

In the period from 1915 to 2013, 848 flood events accounting for 133 deaths were registered [58]. In detail, the events with the most impact occurred in the Kolubara (June 1996; May 2011), Great Morava (July 1999), Kolubara and Drina (June 2001), South Morava (November 2007), West Morava, Drina and Lim (November 2009), Great Timok (February 2010), Pèinja (May 2010), and Drina (December 2010) watersheds [57]. The most critical event occurred in May 2014 (Figure 2), affecting the territories of Serbia, Bosnia-Herzegovina, and Croatia [60]. The precipitation exceeded $200 \mathrm{~mm}$ in a day and was the most dramatic event registered since 1961 [61], affecting more than 1.6 million people (22\% of the country's population) [60]. However, the evacuation procedures were difficult to manage because of the failure of people to move away from hazard areas. Such reactions highlighted a general mistrust of individuals in localities within the government's actions, including evacuations, coupled with low levels of awareness and preparedness [62-64].

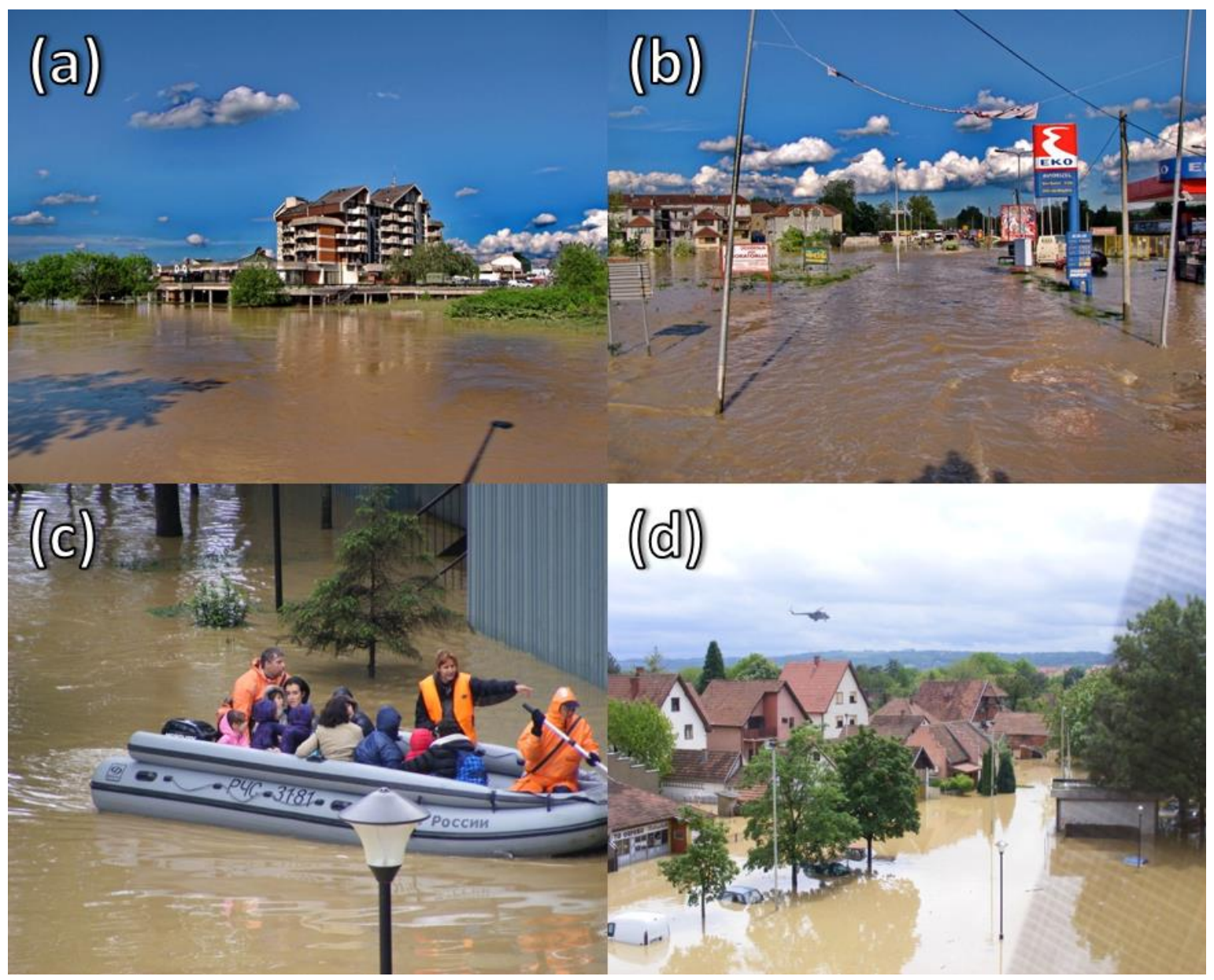

Figure 2. The most critical flood event occurred in 2014 in Serbia. (a) flooded hotel in Obrenovac; (b) flooded streets in Obrenovac; (c) citizen evacuation in Obrenovac; (d) rescue helicopter in Obrenovac.

\section{Materials and Methods}

\subsection{Study Area}

A series of 2500 face-to-face interviews were conducted during the whole of 2015 in 19 of the 191 municipalities in the Republic of Serbia (Table 1). All subjects gave their informed consent for inclusion before they participated in the study, and the University of Belgrade provided ethical 
approval for this research. These communities were chosen for their different demographic and social characteristics, being a census-based representation of the whole population of Serbia. In these municipalities, participants were selected randomly (first stage: parts of the community in the research were selected; second stage: streets or sections of streets were determined by the level of primary causal units; third stage: each research core was determined as the path with specified start and end points of movement; fourth stage: selection of respondents was conducted following the procedure of the next birthday for adult members), with the number of respondents being proportional to its size, using a representative sampling approach [65]. Interviews were carried out for six months, and the participation rate was $96 \%$.

Table 1. Name and ID code of the municipalities involved in the survey. The number of interviews is also shown. The location of the municipalities involved and the complete table of all Serbian municipalities (with ID) are shown in the Supplementary Material (Figure S1; Table S1).

\begin{tabular}{ccc}
\hline ID & Municipality & Interviews \\
\hline 19 & Kraljevo & 141 \\
27 & Šabac & 140 \\
34 & Novi Sad & 150 \\
47 & Obrenovac & 178 \\
57 & Kragujevac & 191 \\
60 & Smederevska Palanka & 205 \\
70 & Smederevo & 145 \\
100 & Rekovac & 50 \\
102 & Kruševac & 180 \\
115 & Paraćin & 147 \\
125 & Batočina & 80 \\
126 & Lapovo & 39 \\
128 & Svilajnac & 115 \\
147 & Sremska Mitrovica & 174 \\
149 & Loznica & 149 \\
151 & Bajina Bašta & 50 \\
152 & Užice & 147 \\
154 & Priboj & 122 \\
182 & Sečanj & 97 \\
\hline
\end{tabular}

\subsection{Demographic Characteristics}

The interviewees, $50.2 \%$ (1256) women and 49.8\% (1244) men (Table 2), were representative of the gendered stratification of the country, which registers $51.3 \%$ women and $48.7 \%$ men [66]. The average age of respondents was 40 years old, and the most represented category was people younger than age $30(711 ; 28.4 \%)$. From the sample, it appears that the majority $(41.7 \%)$ had a secondary (four years) educational degree, and very few completed a higher level of education (university, 20.2\%; doctoral studies, $0.4 \%$ ). In the household sample, married people accounted for $54.6 \%$.

\subsection{Questionnaire Design}

The structured questionnaire was developed using close-ended, multiple choice questions, and 5-point Likert scale questions. The first part of the questionnaire included the socio-demographic characteristics of the interviewees to assess the social background of the respondents and their gender. Subsequent sections included questions related to risk awareness, preparedness, rescue management and assistance, information and education (Appendix A, Table A1). Several published survey approaches were consulted [67-70] and adapted according to the social and flood hazard environment of Serbia. During July 2014, a pilot pre-test of the questionnaire was conducted in Batočina (central Serbia) with 75 people with the aim of checking the comprehensibility and performance of the questionnaire. In that pilot effort, participants were chosen randomly across the municipality and were interviewed in a central location (i.e., the main public square). 
Table 2. Basic socio-economic and demographic information of respondents $(n=2500)$ in a gendered classification. In brackets there are percentages. Missing values in the sums correspond to people that did not complete the questionnaire entirely.

\begin{tabular}{ccccc}
\hline Variable & Category & Total & Male & Female \\
\hline \multirow{2}{*}{ Age (years) } & Young (18-38) & $1265(50.6)$ & $594(46.96)$ & $671(53.04)$ \\
& Adult (39-68) & $1182(47.28)$ & $623(52.71)$ & $559(47.29)$ \\
& Old (>68) & $53(2.12)$ & $27(50.94)$ & $26(49.06)$ \\
\hline \multirow{2}{*}{ Education level } & Compulsory education $^{1}$ & $1987(79.08)$ & $1025(51.58)$ & $962(48.42)$ \\
& University and higher $^{2}$ & $513(20.92)$ & $219(42.69)$ & $294(57.31)$ \\
\hline \multirow{2}{*}{ Marital status } & Single-headed household $^{3}$ & $644(45.36)$ & $317(49.22)$ & $327(50.78)$ \\
& Two-headed household $^{4}$ & $1856(54.64)$ & $927(49.95)$ & $929(50.05)$ \\
\hline \multirow{2}{*}{ Income $^{5}$} & Low income & $1663(66.5)$ & $834(50.15)$ & $829(49.85)$ \\
& High income & $666(33.5)$ & $343(51.50)$ & $323(48.50)$ \\
\hline
\end{tabular}

${ }^{1}$ Primary school degree $(n=180)$; Secondary degree -3 years $(n=520)$; Secondary degree -4 years $(n=1042)$; High school diploma $(n=245) .{ }^{2}$ Bachelor degree $(n=439)$; Master degree $(n=65)$; PhD or equivalent $(n=9) .{ }^{3}$ Single $(n=470)$; Divorced $(n=99)$; Widow/Widower $(n=75) .{ }^{4}$ Married $(n=1856) .{ }^{5}$ Considered below and above the national monthly average net salary. Retrieved from: http:/ / publikacije.stat.gov.rs/G2018/PdfE/G20181260.pdf.

\subsection{Analyses}

Statistical analyses of data were conducted using the Statistical Package for the Social Sciences (SPSS) program (SPSS 20, IBM, Armonk, NY, United States of America ). First, we tested the variable 'gender' to validate our central hypothesis by using a multivariate analysis. A Chi-square test of independence $\left(\chi^{2}\right)$ was used to determine the connection between gender and risk awareness, confidence in the positioning of household furniture, inventory of essentials, evacuation and rescue management, personal assistant of flood victims, economic support reception centers, flood occurrence information, the location of flood risk education, and the source of training. Assessment of the impact level was performed by the phi coefficient, where a higher number indicated a stronger relationship between the two variables [71]. For tables larger than $2 \times 2$, to assess the impact level, we used the Cramer's V coefficient, which considers the number of degrees of freedom. To test the connection between gender and continuous dependent variables regarding individual preparedness, household preparedness, community preparedness, national preparedness, rescue management efficiency, confidence and trust, and unwillingness to get engage, a Pearson correlation was used. Before proceeding to the implementation of the statistical test, we examined the general and specific assumptions to ensure their appropriateness. The internal consistency of Likert scales for the 16 items is good with a Cronbach's alpha of 0.80 . External validity is established by using risk perception to predict intended behaviors to anticipated flooding episodes, giving $\chi^{2}=33.15, p=0.000$.

The interaction between gender and other socio-economic or demographic variables are poorly investigated in disaster research, even if there are fundamental in programming sensitive management and assistance actions. For this reason, we gave insights regarding gender and age, income, marital status and educational level about threat appraisal, preparedness, information and communication of significant variables. We performed analysis of variance and chi-square tests of independence according to the unit of measurements of the variable implied.

\section{Results}

In order to test the central hypothesis of which gender is a predicting variable in all the stages of the disaster cycle, a multivariate regression analysis was used identifying the extent to which seven independent variables were associated with five socio-economic variables: gender, age, education, marital status, and income. According to Table 2 categories, females, young, single-headed households, university and higher educated respondents and high income people have been coded as 0; 1 has been assigned otherwise. Previous analyses showed that the assumptions of normality, linearity, 
multicollinearity and homogeneity of variance had not been violated. The results of the multivariate regressions (Table 3 ) show that the most important predictor of individual preparedness is gender ( $\beta=-0.143)$, and it explains $14.3 \%$ of variance, followed by the marital status $(\beta=-0.092,9.2 \%)$, and the level of education $(\beta=-0.059,5.9 \%)$. The remaining variables (e.g., age and income level) did not have significant effects on individual preparedness. This model $\left(R^{2}=0.032\right.$, Adj. $R^{2}=0.029$, $\mathrm{F}=15.12, t=28.26, p=0.000$ ) with all mentioned independent variables explains the $29.4 \%$ variance and represent a good level of explanation based on standards in psychological research. The most important predictor of household preparedness is gender again $(\beta=-0.049)$ explaining the $4.9 \%$ of variance $\left(R^{2}=0.009\right.$, Adj. $\left.R^{2}=0.007, F=4.36, t=51.25 . p=0.000\right)$. The remaining variables did not have significant effects on household preparedness. Concerning the results of the multivariate regression with flood risk map knowledge information showed that the most important predictor is educational level $(\beta=-0.078)$ explaining the $7.8 \%$ of the variance. Gender did not have significant effect in this model.

Table 3. Results of a multivariate regression analysis concerning individual and household preparedness and flood risk map knowledge $(n=2500)$.

\begin{tabular}{cccccccccc}
\hline \multirow{2}{*}{ Predictor Variable } & \multicolumn{3}{c}{ Individual Preparedness } & \multicolumn{3}{c}{ Household Preparedness } & \multicolumn{3}{c}{ Flood Risk Map Knowledge } \\
\cline { 2 - 9 } & B & SE & $\boldsymbol{\beta}$ & B & SE & $\boldsymbol{\beta}$ & B & SE & $\boldsymbol{\beta}$ \\
\hline Gender & -0.304 & 0.044 & $-0.143^{* *}$ & -0.097 & 0.040 & $-0.049^{*}$ & -0.030 & 0.050 & -0.012 \\
Age & 0.003 & 0.002 & 0.038 & 0.045 & 0.046 & -0.021 & 0.214 & 0.058 & $0.077^{* *}$ \\
Education & 0.050 & 0.019 & $0.059^{*}$ & 0.005 & 0.018 & -0.007 & 0.212 & 0.056 & $-0.078^{* *}$ \\
Marital status & -0.072 & 0.020 & $-0.092^{* *}$ & -0.032 & 0.041 & -0.016 & -0.128 & 0.052 & $-0.051^{*}$ \\
Income & 0.020 & 0.026 & 0.017 & -0.043 & 0.043 & -0.021 & 0.105 & 0.030 & $0.067^{* *}$ \\
\hline
\end{tabular}

${ }^{*} p=0.05 .{ }^{* *} p \leq 0.01$. B: unstandardized (B) coefficients; SE: std. error; $\beta$ : standardized ( $\beta$ ) coefficients.

In the multivariate logistic regression model in Table 4, four independent variables (preventive measures, evacuation consent, personal assistance of flood victims, and supplies) were included. The logistic regression model related to the evacuation consent variable was statistically significant $\chi^{2}=15.024(5, n=2377), p \leq 0.010$ and explains between 6\% (Cox \& Snell) and 11\% (Nagelkerke) of variance. The results of the regression indicated that two predictors have a unique, statistically significant contribution to the model (income level $p<0.01$, and education level $p<0.05$ ) where income is the strongest predictor with an odds ratio of 1.44 . The model including preventive measures information was statistically significant $\chi^{2}=35.968(5, n=2500), p \leq 0.000$ and explains between $14 \%$ (Cox \& Snell) and 26\% (Nagelkerke) of variance. Here the results of the regression indicated that three predictors have a statistically significant contribution to the model (gender $p<0.05$, education level $p<0.05$ and marital status $p<0.01$ ) and gender has the strongest influence with an odds ratio of 1.33 . The model including information of personal assistance of flood victims was statistically significant $\chi^{2}=91.84,(5, n=2500), p \leq 0.000$ and explains between 3.6\% (Cox \& Snell) and 6.1\% (Nagelkerke) of variance. The results of the regression indicated that two predictors have a statistically significant contribution to the model (gender $p<0.01$, and age $p<0.01$ ) and gender has the strongest influence with an odds ratio of 2.44. The model including supplies information was not statistically significant $\chi^{2}=8.78(5, n=2500), p \leq 0.121$ but gender was the only significant predictor with an odds ratio of 1.21 .

From these results we can validate our central hypothesis that gender is a predictive variable in all the stages of the disaster cycle in this research.

\subsection{Risk Awareness}

We were interested in exploring an individual's level of threat appraisal according to a gender perspective. Threat appraisal comprises the product of objectively assessed measures of probability and consequences of risk. In this manuscript, we are evidencing the importance of all these components that construct individuals' conceptualization of flood risk. The results showed a statistically significant difference in the awareness of a flood risk map where women $(87.7 \%)$ had higher scores $(p=0.014)$. 
This can be explained at least in part by educational attainment. That is, women with higher levels of knowledge of flood occurrence (and maps) were also found to have a higher level of education $(p=0.000)$. Furthermore, it was found that married women and men had a higher knowledge when compared to single person families $(p=0.005)$. It appears that single headed households did not have the same concerns as those of two-headed households, perhaps grounded in the carry-over related to increased responsibilities in the family context.

Table 4. Multivariate binary logistic regression analyses used to assess the explanatory power of four chosen predicting variables.

\begin{tabular}{ccccccccc}
\hline \multirow{2}{*}{ Predictor Variable } & \multicolumn{2}{c}{$\begin{array}{c}\text { Preventive } \\
\text { Measures }\end{array}$} & \multicolumn{2}{c}{$\begin{array}{c}\text { Evacuation } \\
\text { Consent }\end{array}$} & \multicolumn{2}{c}{$\begin{array}{c}\text { Personal Assistance of } \\
\text { Flood Victims }\end{array}$} & \multicolumn{2}{c}{ Supplies } \\
\cline { 2 - 9 } & B & SE & B & SE & B & SE & B & SE \\
\hline Gender & $0.287^{*}$ & 0.116 & 0.045 & 0.119 & $0.945^{* *}$ & 0.116 & $0.197^{*}$ & 0.094 \\
Age & 0.113 & 0.132 & -0.088 & 0.141 & $0.625^{* *}$ & 0.140 & -0.167 & 0.107 \\
Education & $-1.49^{*}$ & 0.163 & $-0.329^{*}$ & 0.137 & -0.061 & 0.124 & 0.047 & 0.104 \\
Marital status & $-0.518^{* *}$ & 0.124 & -0.123 & 0.123 & 0.096 & 0.114 & 0.129 & 0.097 \\
Income & -0.229 & 0.123 & $0.371^{* *}$ & 0.125 & 0.127 & 0.121 & -0.093 & 0.101 \\
\hline
\end{tabular}

However, a higher division appeared concerning the health consequences. When asking people to assess their knowledge about the health consequences of floods, it appeared that women $(79.1 \%)$, compared to men $(76.8 \%)$, showed more sensitivity to the health effects associated with flooding, but this was not statistically significant (Table 5). This could be ascribed to a combination of gender effects and the employment status of women. At a glance, women in Serbia are housekeepers and child carers, making them more likely to be more sensitive to environmental threats. Based on a flood likelihood scenario, on a scale of 1 to 5 , it was found that the flooding likelihood of occurrence during the period of one year had a mean value of 2.58 (SD 1.36) for males and 2.53 (SD 1.34) for females, whereas it was 2.84 (SD 1.38) for males and 2.85 (SD 1.37) for females based on a 5-year probabilistic approach (Table 5). Thus, across genders in this study, there was a low awareness that these events would occur in the future, and no statistical differences were found. People seemed to perceive that they are safe from the possible occurrence of these events, even if they displayed specific knowledge about floods and their negative consequences.

Table 5. Pearson correlation and Chi-square test results between risk awareness and gender. Standard deviations are shown in parentheses.

\begin{tabular}{ccccc}
\hline Variable & Sig. (2-Tailed) & Pearson Correlation & Men & Women \\
\hline Awareness of flood probability in 1 year & 0.387 & -0.017 & $2.58(1.36)$ & $2.53(1.34)$ \\
Awareness of flood probability in 5-year & 0.856 & 0.004 & $2.84(1.38)$ & $2.85(1.37)$ \\
Awareness on flood risk locally & 0.020 & $0.330^{*}$ & $2.78(1.25)$ & $2.83(1.25)$ \\
\hline Variable & Sig. (2-Tailed) & $\chi^{2}$ & Men & Women \\
\hline Having flood knowledge & 0.167 & 1.90 & 76.8 & 79.1 \\
Awareness of flood risk map & $0.014^{*}$ & 6.06 & 84.3 & 87.7 \\
Awareness of health risk from flood & 0.064 & 3.42 & 41.2 & 44.9 \\
\hline
\end{tabular}

* Correlation is significant at the 0.05 level (2-tailed).

For this reason, we explored in more detail whether there were some drivers concerning this lack of general awareness from a gender perspective. As expected, respondents with a higher awareness of flood risks perceived a higher flood probability (within 1 year) (men $\bar{x}=2.78$; women $\bar{x}=2.83$ ). In this regard, a higher education has been seen to be a significant determinant $(p=0.021)$ for men for both the flood occurrence scenarios and the opposite for female respondents $(p=0.013)$ underlined women's higher fear derived from a low education. 


\subsection{Flood Preparedness}

The other main focus of this research was an attempt to predict disaster behaviors based on a future scenario. According to the transtheoretical model of change [72], preparedness behavior readiness can be thought of in terms of different 'stages of change': the pre-contemplation, contemplation, preparation, action, and maintenance stages. In total, 2297 people who answered the question 'What stage of preparedness do you feel in response to a possible flood event?', the highest percentage consisted of those who did not intend to change or did not think about changes in the next six months (the so-called pre-contemplation or 'non-thinking') with a value of $60.3 \%$ (Table 6). In addition, as seen in the table, males tended to report more active stages of change (preparation, action, maintenance). Expanding on these premises, the theory of planned behavior [73] clarifies that an individual's intentions to perform a given behavior vary according to a combination of subjective norms and perceived behavioral controls unique to each individual. For this reason, it is interesting to examine how flood preparedness varies across different demographic groups. Such variations reflect the extent to which factors can shape community-driven efforts and education, supporting efforts to be prepared for and cope with flood events.

Table 6. Preparedness level from a gender perspective $(n=2297)$ based on the transtheoretical model. $\mathrm{N}$ stands for a number of respondents.

\begin{tabular}{|c|c|c|c|c|c|}
\hline \multirow{2}{*}{$\begin{array}{l}\text { Preparedness } \\
\text { Level }\end{array}$} & \multirow{2}{*}{ Description } & \multicolumn{2}{|c|}{ Male } & \multicolumn{2}{|c|}{ Female } \\
\hline & & $n$ & $\%$ & $n$ & $\%$ \\
\hline Pre-contemplation & $\begin{array}{l}\text { An individual does not intend to change or does } \\
\text { not consider changes in the short term (in the next } \\
\text { six months) }\end{array}$ & 649 & 56.3 & 735 & 64.2 \\
\hline Contemplation & $\begin{array}{l}\text { An individual is not prepared at present but intends } \\
\text { to undertake certain activities in the next six months }\end{array}$ & 144 & 12.5 & 147 & 12.8 \\
\hline Preparation & $\begin{array}{l}\text { An individual has considered changing his/her } \\
\text { behavior in the next month }\end{array}$ & 141 & 12.2 & 100 & 8.7 \\
\hline Action & $\begin{array}{l}\text { An individual has changed behavior in the recent } \\
\text { past, but the changes did not come to fruition }\end{array}$ & 101 & 8.8 & 75 & 6.6 \\
\hline Maintenance & $\begin{array}{l}\text { An individual has changed his/her behavior, and } \\
\text { these changes were initialized }\end{array}$ & 45 & 3.9 & 37 & 3.2 \\
\hline & Total: & 1153 & 100 & 1144 & 100 \\
\hline
\end{tabular}

These results were also in line with the answers provided when respondents were asked to express from 1 to 5 their level of preparedness at the individual, household, community, and national levels. In fact, women expressed lower levels of self-confidence in being prepared for a flood event, with a mean value of 2.83 versus men with a mean value of $3.13(r=0.142, p=0.000)$. The same pattern of results was found for household preparedness ( 2.99 for women and 3.08 for men, $p=0.019$, $r=0.047)$, highlighting that women were not as confident in household readiness. Any gender statistical difference has been found in regard to community and national preparedness levels, and answers underlined general low scores.

Greater perceived preparedness reported by men might be borne of the fact that, typically in Serbia, they engage in service in the army during which they are trained to manage emergency situations [12]. They are perhaps leading to a more generalized perception of being more proactive and ready when situations call for participation. Cultures, where there are family marginalization and lower levels of involvement in community networks and less preferential treatment for women, may culminate with women evaluating their preparedness to be lower than that of men including when thinking about a possible hazard event reporting to be more exposed to risk. It may also be that women are just more realistic in evaluating personal and household preparedness. As a result, and 
with respect to a starting point for reducing gender-based differences and risks, good knowledge of the surroundings may translate into a more exceptional individual's capacity to cope with natural hazards.

A low level of preparedness was related to lower capacity and willingness to protect $(p=0.001)$. However, men registered a higher propensity in undertaking preventive measures with a significant value of 0.004 and a higher knowledge of the security procedures for responding to a possible flood event $(p=0.000)$. By contrast, women expressed the view that they had no time for dealing with these problems $(r=0.040, p=0.020)$, especially unmarried women (unmarried $\bar{x}=3.38$; married $\bar{x}=2.63$; $p=0.000$ ). That is, women's many household, child-rearing, and related responsibilities may lead to a focus that allows them less time to consider the additional responsibility of being prepared for a possible natural hazard event.

From further analyses, we found significant relationships between preparedness and education, age, marital status and income. Poorly educated men and highly educated women perceived themselves to be the most well prepared (men $p=0.000$; women $p=0.025$ ). Concerning age, both younger female and male felt that they were more equipped compared to adults and elders perceiving a higher level of preparedness as an individual and household level. We found some statistical differences between individual/household preparedness and single women vs. married women (both >than 30 years old) (Individual preparedness: $p=0.000$; Household preparedness: $p=0.000$ ). Married women and men feel to be more prepared to overcome the negative occurrences of floods at both levels. Female-headed households generally perceived themselves to be more vulnerable to floods compared with their counterpart households with both spouses. This could be explained by the fact that households with both spouses are better placed both financially and psychologically. They are therefore able to respond to flood risks in a better mental and emotional state than are their single counterparts. Wealthier men feel to be more risk takers and well equipped $(p=0.008)$, while statistics concerning women were not significant. Generally, people with higher possessions and income feel less vulnerable to the negative occurrence being able to manage the emergency. A higher awareness of flood risks correlated positively with a higher assessment of preparedness (men $p=0.000$; women $p=0.000$ ). This means that a good awareness and preparedness campaign might translate into effective flood preparedness and mitigation measures at the individual and household levels.

Actions useful in the wake of a possible flood event include the handling of utilities (electricity, gas, water). For this reason, we asked people to assess their confidence in dealing with these. It was found that men had higher rates of confidence regarding where water valves $(p=0.000$, male $86.5 \%$, female $73.4 \%$ ), gas valves ( $p=0.000$, male $65.3 \%$, female $42.2 \%)$ and electricity $(p=0.000$, male $87.8 \%$, female $69.9 \%$ ) devices were located in the household (Table 7).

We first asked people whether they stored essential amenities and, second, to choose from a list of which ones they had. More men than women reported having an inventory of essentials useful for the response process ( $27 \%$ and $23 \%$, respectively). It was found that more men (a higher percentage) than women possessed a radio-transistor $(p=0.044)$, shovel $(p=0.000)$, hack $(p=0.000)$, and hoe or spade $(p=0.003)$ (Table 7). On the other hand, a higher percentage of women, compared to men, reported having water storage $(p=0.016)$ and a higher proportion of food supplies (male $59.8 \%$, female $65.3 \%$ ). In our results, women were also found to be more sensitive to essential household content protection, including significantly more women compared to men reporting that they had secured copies of important personal, financial, and insurance documents in a safe place $(p=0.003$, female $31.4 \%$; male $24.2 \%$ ).

\subsection{Evacuation and Rescue Management}

First responders, of course, play an important role in the protection and rescue of people in disasters caused by flooding. When examining the perception of citizens regarding the efficiency of first responder actions on a scale from 1 to 5 , it was found that men displayed slightly greater levels of confidence in planned emergency activities of authorities in almost all the choices provided (efficiency 
of fire department: men (3.56), women (3.44), $r=-0.045$; emergency medical services: men (3.55), women (3.43), $r=-0.44$; headquarters for disasters: men (3.75), women (3.69), $r=0.790$ (Table 8).

Table 7. Pearson correlation and Chi-square test results between flood preparedness and gender. Likert scales means are shown and standard deviations are presented in parenthesis for the first two set of variables.

\begin{tabular}{|c|c|c|c|c|c|}
\hline Category & Variable & Male & Female & Sig. (2-Tailed) & $\begin{array}{c}\text { Pearson } \\
\text { Correlation }\end{array}$ \\
\hline \multirow{4}{*}{ Perception of preparedness } & Individual preparedness & $3.13(1.06)$ & $2.83(1.01)$ & 0.000 & $-0.142 * *$ \\
\hline & Household preparedness & $3.08(0.995)$ & $2.99(0.968)$ & 0.019 & $-0.047 *$ \\
\hline & Community preparedness & $2.96(1.16)$ & $2.94(1.15)$ & 0.568 & -0.012 \\
\hline & National preparedness & $2.84(1.10)$ & $2.88(1.11)$ & 0.310 & 0.020 \\
\hline \multirow{4}{*}{$\begin{array}{l}\text { The reason for not taking } \\
\text { precautions }\end{array}$} & Expectation from others & $2.63(1.36)$ & $2.68(1.29)$ & 0.378 & 0.018 \\
\hline & Expensive & $2.74(1.27)$ & $2.77(1.36)$ & 0.638 & 0.010 \\
\hline & Fail to provide safety & $2.88(1.36)$ & $2.91(1.25)$ & 0.077 & 0.036 \\
\hline & Not prevent the consequences & $2.86(1.36)$ & $2.92(1.35)$ & 0.401 & 0.017 \\
\hline Category & Variable & Male & Female & Sig. (2-Tailed) & $\chi^{2}$ \\
\hline \multirow{2}{*}{ Inventory of essentials } & Water storage & 41.3 & 51.7 & $0.016^{*}$ & 8.240 \\
\hline & Food & 59.8 & 65.3 & 0.298 & 0.350 \\
\hline \multirow{3}{*}{$\begin{array}{l}\text { Confidence in the positioning } \\
\text { of house furniture }\end{array}$} & Water valves & 86.5 & 73.4 & $0.000 * *$ & 77.85 \\
\hline & Gas valves & 65.3 & 42.2 & $0.000 * *$ & 112.1 \\
\hline & Electricity & 87.8 & 69.9 & $0.000 * *$ & 110.2 \\
\hline
\end{tabular}

* Correlation is significant at the 0.05 level (2-tailed), ${ }^{* *}$ Correlation is significant at the 0.01 level (2-tailed).

Table 8. Pearson correlation and Chi-square test results between gender and evacuation and rescue management. Likert scales means are shown, and standard deviations are presented in parenthesis for the first two set of variables.

\begin{tabular}{|c|c|c|c|c|c|}
\hline Category & Variable & Men & Women & Sig. (2-Tailed) & $\begin{array}{c}\text { Pearson } \\
\text { Correlation }\end{array}$ \\
\hline \multirow{5}{*}{$\begin{array}{c}\text { Rescue } \\
\text { management } \\
\text { efficiency }\end{array}$} & Police efficiency & $3.30(1.29)$ & $3.27(1.27)$ & -0.013 & 0.528 \\
\hline & Fire Department efficiency & $3.56(1.27)$ & $3.44(1.31)$ & 0.021 & $-0.045 *$ \\
\hline & Ambulance service efficiency & $3.55(1.17)$ & $3.44(1.27)$ & 0.019 & $-0.44 *$ \\
\hline & Army efficiency & $3.75(1.30)$ & $3.69(1.36)$ & 0.245 & -0.024 \\
\hline & Headquarters emergency situations efficiency & $3.35(1.32)$ & $3.36(1.40)$ & 0.005 & $0.790 * *$ \\
\hline \multirow{11}{*}{$\begin{array}{c}\text { Confidence and } \\
\text { trust }\end{array}$} & Family member & $4.20(1.27)$ & $4.31(1.18)$ & 0.037 & $0.042 *$ \\
\hline & Neighbors & $3.56(1.28)$ & $3.63(1.21)$ & 0.148 & 0.029 \\
\hline & International humanitarian organization & $2.39(1.18)$ & $2.43(1.11)$ & 0.419 & 0.016 \\
\hline & Non-governmental organization & $2.46(1.21)$ & $2.50(1.13)$ & 0.379 & 0.018 \\
\hline & Religious community & $2.31(1.25)$ & $2.47(1.19)$ & 0.002 & $0.064^{* *}$ \\
\hline & Police & $3.25(1.37)$ & $3.36(1.25)$ & 0.043 & $0.041 *$ \\
\hline & Fire department & $3.63(2.27)$ & $3.61(1.19)$ & 0.726 & -0.007 \\
\hline & Emergency head & $3.48(1.23)$ & $3.40(1.24)$ & 0.122 & -0.031 \\
\hline & Army & $3.56(1.36)$ & $3.58(1.32)$ & 0.768 & 0.006 \\
\hline & Self-organized & $3.14(1.33)$ & $3.06(1.34)$ & 0.166 & -0.028 \\
\hline & Variable & Men & Women & Sig. (2-Tailed) & $x^{2}$ \\
\hline \multirow{6}{*}{ Escape route } & Consent to evacuate & 52.6 & 47.4 & $0.023 *$ & 0.880 \\
\hline & Home-higher floors & 52.6 & 39.9 & & \\
\hline & Friends' house & 39.9 & 32.2 & & \\
\hline & Neighbors & 9.4 & 52.6 & $0.000 * *$ & 22.24 \\
\hline & Reception centers & 10.7 & 16 & & \\
\hline & Empty/Safer apartments & 2.9 & 96.3 & & \\
\hline \multirow{2}{*}{ Evacuation plan } & Evacuation plan for vulnerable family members & 3.5 & 4 & $0.005^{* *}$ & -0.06 \\
\hline & Family dialogue on evacuation plan & 16.6 & 14 & 0.117 & 4.28 \\
\hline
\end{tabular}

** Correlation is significant at the 0.01 level (2-tailed), ${ }^{*}$ Correlation is significant at the 0.05 level (2-tailed). 
Generally speaking, and in contrast to the standpoint of the answers given, the trust in family members as actors from whom help could be expected was significantly more pronounced for women compared to men, with mean values of 4.31 and 4.20 , respectively $(r=0.042, p=0.037)$. Some slight gender differences were also found regarding confidence and trust in different organizations. Females tended to rely more on police activities $(r=0.041, p=0.043$, male $\bar{x}=3.25$, female $\bar{x}=3.36$ ); international humanitarian organizations ( $p=0.043$, male $\bar{x}=2.46$, female $\bar{x}=2.50$ ), non-governmental humanitarian agencies (male $\bar{x}=2.30$, female $\bar{x}=2.34$ ), neighbors (male $\bar{x}=3.56$, female $\bar{x}=3.63$ ), religious community affiliations $(r=0.064, p=0.002$, male $\bar{x}=2.38$, female $\bar{x}=2.43$ ), and the army (male $\bar{x}=3.56$, female $\bar{x}=3.58$ ). Males, in reverse, tended towards a higher confidence in the fire department (male $\bar{x}=3.63$, female $\bar{x}=3.61$ ), emergency aid bodies (male $\bar{x}=3.48$, female $\bar{x}=3.40$ ), and themselves (male $\bar{x}=3.14$, female $\bar{x}=3.06$ ). Similar results were found in a study regarding trust in Serbia, which observed that the church, the police, and the army were the three principal organs in which people trusted the most for crisis management (Table 8) [66].

In contrast to the literature, in this research, it was found that men (52.6\%) reported being more willing to accept evacuation orders compared to women $(47.4 \%)(p=0.023)$ and especially low income men $(p=0.002)$. An examination of the preferred evacuation strategies revealed statistically significant differences across all items. Men preferred to remain in the house, but moving to higher floors (male $52.6 \%$, female $39.9 \%$ ) or go to friends' places (male $39.9 \%$, female $32.2 \%$ ). It seems that men have less confidence in the escape routes of public authorities even if they accepted evacuate orders. They expressed a preference for remaining in their houses or going to people located close by. On the other hand, women would evacuate to neighbors (female $52.6 \%$, male $9.4 \%$ ), to designated reception centers (female $16 \%$, male $10.7 \%$ ), and other empty/safer apartments (female $3.7 \%$, male $2.9 \%)(p=0.000$ ) (Table 8).

Keeping oral or written response plans can also significantly contribute to more efficient evacuation strategies at the household level. For this reason, we asked people to state whether they had a plan for possible evacuation or whether they had ever held planning discussions in the case of an upcoming flood event. Although generally low rates of the possession of written plans were reported, women $(4 \%)$ displayed a slightly higher percentage compared to men $(3.5 \%)(p=0.005)$. Additionally, females (55.2\%), when compared to males (51.5\%), displayed higher sensitivity to the evacuation procedures of the elderly, the disabled, and infants. There was no statistically significant difference between men and women regarding planning discussions in the case of an upcoming flood event. Here again, women demonstrated more sensitivity in taking care of aspects of household organization and safety.

\subsection{Assistance}

Gender was also evaluated as a variable predicting the willingness to assist, with men more likely to report being a volunteer during a disaster compared to women. Men (23.5\%), compared to women $(11.1 \%)$, reported greater assistance of flood victims, as well as higher participation with respect to economic support (men $28.1 \%$, women $6.1 \% ; p=0.004$ ). This latter form of assistance can be considered as 'passive engagement' (Table 9). A more active participation was detected from the women's side; however, generally low base rates were reported, indicating that women $(6.1 \%)$ demonstrated significantly more proactive attitudes about effective assistance at reception centers compared to men $(3.7 \%)(p=0.000)$.

Young women $(p=0.008)$ and men $(p=0.032)$ consider more to be engaged in assistantship to flood victims also providing economic support. The same results have been found for married individuals concerning both genders. To recall previous results, it seems that the lack of time and the higher vulnerability of single individual families make them less interested in getting engaged in the recovery process. Unexpectedly, low income women $(p=0.000)$ and men $(p=0.000)$ are more prone to support financially flood victims. This behavior is translated might be seen as 'unquestioning obedience' or 'altruism' that often comes from less wealthy individuals. 
Table 9. Pearson correlation and Chi-square test results between assistance and gender. Likert scales mean are shown and standard deviations are presented in parenthesis for the first set of variables.

\begin{tabular}{cccccc}
\hline Category & Variable & Men & Women & Sig. (2-Tailed) & $\begin{array}{c}\text { Pearson } \\
\text { Correlation }\end{array}$ \\
\hline & Any difference & $2.65(1.24)$ & $2.58(1.25)$ & 0.217 & -0.026 \\
Expected from others & $2.76(1.21)$ & $2.70(1.22)$ & 0.294 & -0.22 \\
become engaged & State body tasks & $2.98(1.21)$ & $2.93(1.22)$ & 0.316 & -0.021 \\
& Expected from peers & $2.98(1.21)$ & $2.93(1.27)$ & 0.041 & $-0.043^{*}$ \\
& Lack of time & $2.42(1.19)$ & $2.29(1.20)$ & 0.338 & -0.020 \\
\hline & High cost & $2.65(1.27)$ & $2.42(1.20)$ & 0.007 & $-0.056^{* *}$ \\
\hline \multirow{2}{*}{ Type of assistance } & Variable & Male & Female & Sig. (2-Tailed) & $\chi^{2}$ \\
& Personal assistance of flood victims & 23.5 & 11.1 & $0.000^{* *}$ & 63.6 \\
& Economic support & 28.1 & 33.6 & $0.004^{* *}$ & 8.38 \\
\hline
\end{tabular}

** Correlation is significant at the 0.01 level (2-tailed), ${ }^{*}$ Correlation is significant at the 0.05 level (2-tailed).

\subsection{Information and Education}

When people were asked to state the source from which they received information on floods, a gender-based relationship emerged (Table 10). Women stated to be informed by technological sources (television, press, and the Internet) and family; while their male counterparts, reported to rely more on neighbors, friends, and the place of work for their information. This might be explained by the fact that women are typically confined in the house, for their work and child rearing, making them isolated from various sources of communication, except other family members.

Table 10. Chi-square test results between gender and information and education-predicting variables.

\begin{tabular}{cccccc}
\hline Category & Variable & Male & Female & $\chi^{2}$ & Sig. (2-Tailed) \\
\hline & Family members & 29.3 & 33.1 & 3.87 & $0.015^{*}$ \\
& Neighbors & 18.3 & 13.8 & 8.46 & $0.049^{*}$ \\
& Friends & 12.3 & 9.5 & 4.47 & $0.004^{* *}$ \\
& Relatives & 12.7 & 11.3 & 0.995 & $0.034^{*}$ \\
Flood occurrence & School & 12.8 & 15.4 & 3.23 & 0.319 \\
information & College & 6.9 & 4.5 & 5.72 & 0.072 \\
& Work & 16.8 & 11.8 & 11.80 & $0.017^{*}$ \\
& Religious community & 2.8 & 2.4 & 0.199 & $0.001^{* *}$ \\
& Television & 54.8 & 63 & 16.27 & 0.655 \\
& Radio & 16.3 & 15.2 & 0.403 & $0.000^{* *}$ \\
& Press & 29.5 & 33.9 & 5.11 & 0.526 \\
The place of flood & Internet & 24.4 & 33 & 20.74 & $0.024^{*}$ \\
risk education & School & 36.5 & 28.7 & 2.11 & $0.347^{* *}$ \\
& Family & 41.4 & 44.1 & 4.92 & $0.000^{* *}$ \\
& Work & 36.5 & 28.7 & 16.88 & $0.000^{* *}$ \\
\hline \multirow{2}{*}{ Source of training } & Television & 62.3 & 62.4 & 0.000 & 1.00 \\
& Radio & 13.3 & 11.8 & 1.20 & 0.273 \\
& Video games & 3.1 & 0.5 & 20.11 & $0.000^{* *}$ \\
& Internet & 20.6 & 28 & 10.01 & $0.000^{* *}$ \\
\hline
\end{tabular}

** Correlation is significant at the 0.01 level (2-tailed), ${ }^{*}$ Correlation is significant at the 0.05 level (2-tailed).

By contrast, men may have more opportunities through greater interaction with the community. Furthermore, 38\% of both women and men expressed a strong desire to get trained on the correct response actions in the wake of a possible flood event through the Internet or TV. Internet was the most preferred by married individuals, young people and low income respondents. Low educated $(p=0.000)$ and young men $(p=0.000)$ stated to prefer to get trained by videogames. For this reason, we asked people to assess whether they had received education on these hazards by mentioning the sources involved. Among school, family, and work, people seemed to consider family as the main 
source of education for floods, with a higher and statistically significant percentage of women with respect to men $(p=0.000)$. On the other hand, men $(36.5 \%)$, with a higher percentage than women $(28.7 \%)$, noted that their place of work was the main source of education about flood hazards $(p=0.000)$. Education from school received lower rates of endorsement among both men and women $(26.5 \%)$ (Table 10).

\section{Discussion}

This research suggests that in Serbia, there may be gender differentiation across phases of the disaster cycle. However, it is important to note that it is not just a matter of difference, as underlined by Gustafson [74]. Gender is not a merely a variable that assesses the differences between men and women in the wake of disasters. It is also how living conditions, demographic and economic attributes, behaviors and beliefs reflect gender power relations in this context. Once recognized, rather than expose problems exclusively, disasters and disaster preparedness can also be seen as opportunities to facilitate or provide openings for the empowerment of traditionally marginalized groups [75].

Assessing gender discrepancies can help policy makers recognize local capacities and provide prospects for the less powerful to make disaster preparedness and relief more effective. The failure in understanding local relationships and social networks may disadvantage communities including women, men and their families and networks who face these events. One pathway for learning and integrating gender in emergency management practices includes successful stories. For example, in Bangladesh, with the introduction of improved gender-responsive disaster management, Cyclone Sidr in 2007 took a lower number of female lives when compared to previous disasters and before this policy [76]. Similar records have been found in response to tropical cyclones in Vanuatu in the South Pacific Ocean. In his report for Care International, Webb [77] demonstrated that gender-sensitive disaster risk reduction (DRR) programming contributed to reducing the impact and damage from Cyclone Pam when compared to a community that did not undertake the same plan. In Macedonia, the UNDP [78] included and trained women at the National Crisis Management Center for earthquake and flood preparedness. This initiative, undertaken in 2008, served as a best practice for gender inclusion in DRR that led to the drafting of gender-sensitive risk management plans at a national level. Successful community-based management actions depend on how public authorities' mainstream the preparedness and recovery of men and women after disaster events, and how well gender-different realities are noticed and dealt with. Thus, to assist public authorities to organize gender-sensitive management plans, it is necessary to know how people differentially prepare and react to catastrophic events from a gender perspective.

Gender dynamics in the disaster context should be of interest to government, non-governmental, and international organizations and projects and not only at policy levels. They should also be a priority for researchers and emergency management practitioners, who need to contribute more in their studies and their practice to find a gender differentiation in how men and women perceive, prepare for, tolerate, and react to natural disasters, including in combination with different socio-cultural and economic backgrounds.

\section{Conclusions}

In this work, gender differences were found in a large sample in Serbia regarding a range of flood preparedness indicators. Although there were some variables that indicated no significant or slight differences, larger magnitude and significant differences appeared to revolve around men's perceptions of being more prepared and being more active or willing to be involved in or led by community-level activities. Women generally reported being less confident, but perhaps had more realistic views about being prepared while also reporting more household- and family-level cares, concerns, and preparedness behaviors in selected areas. Such a pattern may be underpinned, at least to some extent, by gender-specific roles linked to the household and to community access, leading to a state of affairs that lead to less ability to connect with active social networks within the community, 
coupled with being less informed and able to be involved in larger decision-making processes. For this purpose, planners might consider how this may affect the way authorities can reach those people with hazard information and emergency warnings. Importantly, based on current findings coupled with other research on different gender profiles, both women and men should be seen as valuable resources that might combine complementary strengths to maximize preparedness, response, and recovery. That is, promoting more gender-related dialogue that aims to leverage the respective strengths of women and men and requires women to be increasingly empowered to take leading roles in building disaster resilience. In this work, females reported greater organization of essential supplies and emergency amenities, saving important documents, and dealing with the financial matters of the household. This should be taken not only as an advantage, but also perhaps as a proxy for a more embedded sense of prioritizing the security of the household, which makes them more motivated for arranging household and family concerns. This includes emphasizing their role in emergency management messaging for preparing the family for a possible hazard situation. Men appeared to be more confident in managing an emergency situation, including the perception that they were better prepared to take action, including physical preparedness and response. Additionally, women had fewer opportunities to maintain a high level of social networking in the community, which may lead to them being less informed. This might then underpin women expressing TV as the main channel of flood hazard information and education. Regarding the main outcomes of this research, at a political level, it is thus important to:

- Learn more about and emphasize the role of women and men in emergency management planning and messaging;

- Engage in more in-depth research on gender roles, including more in-depth qualitative or mixed methods research that uses interviewing and/or focus group methodologies on gathering more in-depth information;

- Develop strategies to empower women, educate men, and promote the genders working together synergistically to prepare effectively while also perhaps, at the same time, overcoming gender stereotypes;

- Promote gender-sensitive preparedness by using networks that appeal to and advocate for women, including those that have a long history of assessing and addressing public health issues (e.g., women's social and health care providers);

- Use a range of communication channels for increasing hazard knowledge and preparedness, including gender-related scenarios or case studies that appeal to people and promote empowerment and working cooperatively together within households and communities;

- Include flood hazard education in children's school curricula (e.g., education on gender empowerment and cooperation in the context of creating a current and future population that has resilience and risk management knowledge and skills) with the purpose to prepare for and solve problems linked to a range of risk scenarios in life such as flooding and other natural hazards.

Based on the current quantitative research, there is an increasing need for more gender-focused mixed methods research to contextualize gender discrepancies in more depth and at a local scale. Doing so can better target and tailor disaster management planning and preparedness, response, and recovery education campaigns. Such work could result, perhaps even quite significantly, in fewer victims of events such as floods, lessening economic losses, and reducing other consequences.

Supplementary Materials: The following are available online at http:/ / www.mdpi.com/1660-4601/15/12/2761/ s1, Figure S1: Study areas location (grey). Numbers refer to the ID of the municipality, Table S1: The ID of the municipality and belonging county in Serbia.

Author Contributions: V.M.C. conceived and designed the questionnaire with inputs from A.Ö. and S.D. V.M.C. contributed to acquisition and analyzed the data. G.R. interpreted the data and prepared the manuscript drafts. V.M.C., G.R., A.Ö., P.T. and S.D. critically reviewed the data analysis and contributed to the content for revising and finalizing the manuscript. 
Funding: This research was funded by European Union's Horizon 2020 research and innovation program under Grant Agreement No. 740750.

Acknowledgments: We would like to thank Kevin Ronan, who provided us professional advice throughout the writing and data interpretation.

Conflicts of Interest: The authors declare no conflict of interest.

\section{Appendix A}

Table A1. Set of questionnaire variables and units of measurement.

\begin{tabular}{|c|c|}
\hline Variable & Units of Measurement \\
\hline \multicolumn{2}{|l|}{ Threat appraisal } \\
\hline Flood knowledge & Dummy variable (yes/no/not sure) \\
\hline Flood risk map knowledge & Dummy variable (yes/no/not sure) \\
\hline Flood-related health risks & Dummy variable (yes/no/not sure) \\
\hline 1-year flood likelihood scenario & 5-Point Likert scale \\
\hline 5-year flood likelihood scenario & 5-Point Likert scale \\
\hline Feeling of danger & 5-Point Likert scale \\
\hline \multicolumn{2}{|l|}{ Flood preparedness } \\
\hline Preparedness & Transtheoretical model (Citizens Corps 2006) \\
\hline Individual preparedness & 5-Point Likert scale \\
\hline Household preparedness & 5-Point Likert scale \\
\hline Community preparedness & 5-Point Likert scale \\
\hline National preparedness & 5-Point Likert scale \\
\hline Unwillingness to protect & $\begin{array}{l}\text { Multiple choice question: (1) Expectation from others, } \\
\text { (2) Not being at risk, (3) Not having time, (4) } \\
\text { Expensive, (5) Fail to provide safety, (6) Not prevent } \\
\text { the consequences }\end{array}$ \\
\hline Preparation usefulness for the future & 5-Point Likert scale \\
\hline Confidence in the positioning of house furniture & $\begin{array}{l}\text { Dummy variable (yes/no): (1) Water valves, (2) Gas } \\
\text { valves, (3) Electricity }\end{array}$ \\
\hline Confidence in handling house furniture & $\begin{array}{l}\text { Dummy variable (yes/no): (1) Water valves. (2) Gas } \\
\text { valves, (3) Electricity }\end{array}$ \\
\hline Inventory of essentials & $\begin{array}{l}\text { Dummy variable (yes/no): (1) radio-transistor, ( } 2 \text { ) } \\
\text { shovel, (3) hack, (4) hoe, spade, (5) water storage, (6) } \\
\text { food }\end{array}$ \\
\hline Confidence in the location of financial documents & Dummy variable (yes/no) \\
\hline \multicolumn{2}{|l|}{ Evacuation and rescue management } \\
\hline Escape route & $\begin{array}{l}\text { Multiple choice question: (1) Home- Higher floors, (2) } \\
\text { Friends' house, (3) Neighbors, (4) Reception centers, } \\
\text { (6) Empty/Safer apartments }\end{array}$ \\
\hline Consent to evacuate & Dummy variable (yes/no) \\
\hline Family dialogue on evacuation plan & Dummy variable (yes/no) \\
\hline Evacuation plan for vulnerable family members & Dummy variable (yes/no) \\
\hline Rescue management efficiency & $\begin{array}{l}\text { 5-Point Likert scale: (1) Police, (2) Fire Department, } \\
\text { (3) Ambulance service, (4) Army, (5) Headquarters } \\
\text { emergency situations }\end{array}$ \\
\hline Confidence and trust & $\begin{array}{l}\text { 5-Point Likert scale: (1) Family member, (2) } \\
\text { Neighbors, (3) International humanitarian } \\
\text { organization, (4) Non-governmental organization, (5) } \\
\text { Religious community, (6) Police, (7) Fire department, } \\
\text { (8) Emergency head, (9) Army, (10) Self-organized }\end{array}$ \\
\hline \multicolumn{2}{|l|}{ Assistance } \\
\hline Willingness to assist community recovery & Dummy variable (yes/no) \\
\hline Type of assistance & $\begin{array}{l}\text { Dummy variable (yes/no): (1) Personal assistance of } \\
\text { flood victims, (2) Economic support (3) Reception } \\
\text { Centers }\end{array}$ \\
\hline Unwillingness to become engaged & $\begin{array}{l}\text { Level of agreement on a 5-point Likert scale: (1) Any } \\
\text { difference, (2) Expected from others, (3) State body } \\
\text { task, (4) Expected from peers, (5) Lack of time, (6) } \\
\text { High cost }\end{array}$ \\
\hline \multicolumn{2}{|l|}{ Information and education } \\
\hline & Dummy variable (yes/no): (1) Family members, (2) \\
\hline Flood occurrence information & Neighbors, (3) Friends, (4) Relatives, (5) School, (6) \\
\hline Flood occurrence information & College, (7) Work, (8) Religious community, (9) \\
\hline & Television, (10) TV, (11) Radio, (12) Press, (13) Internet \\
\hline Flood risk education & $\begin{array}{l}\text { Dummy variable (yes/no): (1) School, (2) Family, (3) } \\
\text { Work }\end{array}$ \\
\hline Desire to be trained & Dummy variable (yes/no) \\
\hline Preferable training source & $\begin{array}{l}\text { Dummy variable (yes/no): (1) Television, (2) Radio, } \\
\text { (3) Video games, (4) Internet, (5) Lecture }\end{array}$ \\
\hline
\end{tabular}




\section{References}

1. Bankoff, G. The Tale of the Three Pigs: Taking Another Look at Vulnerability in the Light of the Indian Ocean Tsunami and Hurricane Katrina. Available online: http:/ / understandingkatrina.ssrc.org/Bankoff/ (accessed on 16 September 2018).

2. Obcarskaite, E. Women in Civil Protection: Gender Equality and Gender Mainstreaming-Towards Prosperity in the Baltic Sea Region. In Handbook on: Gender in Civil Protection; Obcarskaite, E., Olsson, A.J., Eds.; KOPA Publishing: Karmèlavos sen, Lithuania, 2014; ISBN 978-91-981257-8-8.

3. Wisner, B.; Blaikie, P.; Cannon, T.; Davis, I. At Risk: Natural Hazards, People's Vulnerability and Disasters; Routledge: London, UK, 1994; p. 134. ISBN 978-0-203-44423-8.

4. Gutteling, J.M.; Wiegman, O. Gender-specific reactions to environmental hazards in The Netherlands. Sex Roles 1993, 28, 433-447. [CrossRef]

5. Greenberg, M.R.; Schneider, D.F. Gender differences in risk perception: Effects differ in stressed vs. nonstressed environments. Risk Anal. 1995, 15, 503-511. [CrossRef] [PubMed]

6. Riechard, D.E.; Peterson, S.J. Perception of Environmental Risk Related to Gender, Community Socioeconomic Setting, Age, and Locus of Control. J. Environ. Educ. 1998, 30, 11-19. [CrossRef]

7. Fordham, M. The intersection of gender and social class in disaster: Balancing resilience and vulnerability. Int. J. Mass Emerg. Disasters 1999, 17, 15-37. [PubMed]

8. Norris, F.H.; Perilla, J.L.; Ibaiiez, G.E.; Murphy, A.D. Sex Differences in Symptoms of Posttraumatic Stress: Does Culture Play a Role? J. Trauma Stress 2001, 14, 7-28. [CrossRef]

9. Overton, L.R.-A. From Vulnerability to Resilience: An Exploration of Gender Performance Art and how it has Enabled Young women's Empowerment in Post-hurricane new Orleans. Procedia Econ. Financ. 2014, 18, 214-221. [CrossRef]

10. Gomez, S. Guidelines for Gender Sensitive Disaster Management: Practical Steps to Ensure Women's Needs Are Met and Women's Human Rights Are Respected and Protected during Disasters; Chiang, M., Ed.; Asia Pacific Forum on Women Law and Development (APWLD): Chiang Mai, Thailand, 2006.

11. The United Nation Office for Disaster Risk Reduction (UNISDR). Sendai Framework for Disaster Risk Reduction 2015-2030; United Nation Publications: Geneva, Switzerland, 2015; p. 37.

12. Baćanović, V. Gender Analysis of the Impact of the 2014 Floods in Serbia. Organization for Security and Cooperation in Europe (OSCE). Available online: https: / www.osce.org/serbia/135021?download=true (accessed on 4 December 2018).

13. Fromm, J. Risk Denial and Neglect: Studies in Risk Perception; Elanders Gotab Publishing: Stockholm, Sweden, 2005; p. 160.

14. Slovic, P.; Finucane, M.L.; Peters, E.; MacGregor, D.G. Risk as analysis and risk as feelings. Risk Anal. 2004, 24, 311-322. [CrossRef]

15. Griffin, R.J.; Yang, Z.; ter Huurne, E.; Boerner, F.; Ortiz, S.; Dunwoody, S. After the Flood: Anger, Attribution, and the Seeking of Information. Sci. Commun. 2008, 29, 285-315. [CrossRef]

16. O'Neill, E.; Brereton, F.; Shahumyan, H.; Clinch, J.P. The Impact of Perceived Flood Exposure on Flood-Risk Perception: The Role of Distance. Risk Anal. 2016, 36, 2158-2186. [CrossRef]

17. Cutter, S.L.; Tiefenbacher, J.; Solecki, W.D. En-Gendered Fears: Femininity and Technological Risk Perception. Ind. Cris. Q. 1992, 6, 5-22. [CrossRef]

18. Paradise, T.R. Perception of earthquake risk in Agadir, Morocco: A case study from a Muslim community. Environ. Hazards 2005, 6, 167-180. [CrossRef]

19. Lavigne, F.; De Coster, B.; Juvin, N.; Flohic, F.; Gaillard, J.C.; Texier, P.; Morin, J.; Sartohadi, J. People's behaviour in the face of volcanic hazards: Perspectives from Javanese communities, Indonesia. J. Volcanol. Geotherm. Res. 2008, 172, 273-287. [CrossRef]

20. De Silva, K.; Jayathilaka, R. Gender in the context of Disaster Risk Reduction; A Case Study of a Flood Risk Reduction Project in the Gampaha District in Sri Lanka. Procedia Econ. Financ. 2014, 18, 873-881. [CrossRef]

21. Morrow Hearn, B.; Enarson, E. Hurricane Andrew throught Women's eyes: Issues and Reccommendations. Int. J. Mass Emerg. Disasters 1996, 14, 5-22.

22. De Marchi, B.; Scolobig, A.; Delli Zotti, G.; Del Zotto, M. Risk Construction and Social Vulnerability in An Italian Alpine Region. Available online: http:/ / www.floodsite.net/html/partner_area/project_docs / task11_p33_06-08_final.pdf (accessed on 4 December 2018). 
23. Gregg, C.E.; Houghton, B.F.; Johnston, D.M.; Paton, D.; Swanson, D. The perception of volcanic risk in Kona communities from Mauna Loa and Hualalai volcanoes, Hawaii. J. Volcanol. Geotherm. Res. 2004, 130, 179-196. [CrossRef]

24. Armaş, I.; Avram, E. Perception of flood risk in Danube Delta, Romania. Nat. Hazards 2009, 50, $269-287$. [CrossRef]

25. Eiser, J.R.; Donovan, A.; Sparks, R.S.J. Risk Perceptions and Trust Following the 2010 and 2011 Icelandic Volcanic Ash Crises. Risk Anal. 2015, 35, 332-343. [CrossRef]

26. Kunreuther, H. Disaster Mitigation and Insurance: Learning from Katrina. Ann. Am. Acad. Pol. Soc. Sci. 2006, 604, 208-227. [CrossRef]

27. Barberi, F.; Davis, M.S.; Isaia, R.; Nave, R.; Ricci, T. Volcanic risk perception in the Vesuvius population. J. Volcanol. Geotherm. Res. 2008, 172, 244-258. [CrossRef]

28. Armaş, I. Social vulnerability and seismic risk perception. Case study: The historic center of the Bucharest Municipality/Romania. Nat. Hazards 2008, 47, 397-410. [CrossRef]

29. Miceli, R.; Sotgiu, I.; Settanni, M. Disaster preparedness and perception of flood risk: A study in an alpine valley in Italy. J. Environ. Psychol. 2008, 28, 164-173. [CrossRef]

30. Roder, G.; Ruljigaljig, T.; Lin, C.-W.; Tarolli, P. Natural hazards knowledge and risk perception of Wujie indigenous community in Taiwan. Nat. Hazards 2016, 81, 641-662. [CrossRef]

31. Lindell, M.K.; Whitney, D.J. Correlates of household seismic hazard adjustment adoption. Risk Anal. 2000, 20, 13-25. [CrossRef] [PubMed]

32. Baker, E.J. Household preparedness for the Aftermath of Hurricanes in Florida. Appl. Geogr. 2011, 31, 46-52. [CrossRef]

33. Able, E.K.; Nelson, M.K. (Eds.) Circles of Care: Work and Identity in Women's Lives; SUNY Press: Albany, NY, USA, 1990.

34. FEMA. Personal Preparedness in America: Findings from the 2009 Citizen Corps National Survey; FEMA: Washington, DC, USA, 2009.

35. Bateman, J.M.; Edwards, B. Gender and Evacuation: A Closer Look at Why Women Are More Likely to Evacuate for Hurricanes. Nat. Hazards Rev. 2002, 3, 107-117. [CrossRef]

36. Enarson, E. Gender Mainstreaming in the Emergency Management: A Training Module for Emergency Planner; York University: Toronto, ON, Canada, 2006.

37. Motoyoshi, T. Public Perception of Flood Risk and Community-based Disaster Preparedness. In A Better Integrated Management of Disaster Risks: Toward Resilient Society to Emerging Disaster Risks in Mega-Cities; Ikeda, S., Fukuzono, T., Sato, T., Eds.; Terra Scientific Publishing Company, 2006; pp. 121-134. Available online: http:/ / www.terrapub.co.jp/e-library/nied/pdf/121.pdf (accessed on 4 December 2018).

38. Scolobig, A.; De Marchi, B.; Borga, M. The missing link between flood risk awareness and preparedness: Findings from case studies in an Alpine Region. Nat. Hazards 2012, 63, 499-520. [CrossRef]

39. Terpstra, T. Emotions, Trust, and Perceived Risk: Affective and Cognitive Routes to Flood Preparedness Behavior. Risk Anal. 2011, 31, 1658-1675. [CrossRef] [PubMed]

40. Helsloot, I.; Ruitenberg, A. Citizen response to disaster; a reviw of literature and some applications. J. Contigency Cris. Manag. 2004, 12, 97-111.

41. Mileti, D.S. (Ed.) Disasters by Design: A Reassessment of Natural Hazards in the United States; Joseph Henry Press: Washington, DC, USA, 1999.

42. Okun, M.A.; Michel, J. Sense of Community and Being a Volunteer Among the Young-Old. J. Appl. Gerontol. 2006, 25, 173-188. [CrossRef]

43. Olczyk, M.E. Flood Risk Perception in the Red River Basin, Manitoba: Implications for Hazard and Disaster Management. Master's Thesis, University of Manitoba Winnipeg, Winnipeg, MB, Canada, 2004.

44. Ivanov, A.; Cvetković, V. The Role of Education in Natural Disaster Risk Reduction. Horiz. Int. Sci. J Ser. A Soc. Sci. Hum. 2014, 16, 115-130.

45. Bradford, R.A.; O'Sullivan, J.J.; van der Craats, I.M.; Krywkow, J.; Rotko, P.; Aaltonen, J.; Bonaiuto, M.; De Dominicis, S.; Waylen, K.; Schelfaut, K. Risk perception-Issues for flood management in Europe. Nat. Hazards Earth Syst. Sci. 2012, 12, 2299-2309. [CrossRef]

46. Brilly, M.; Polic, M. Public perception of flood risks, flood forecasting and mitigation. Nat. Hazards Earth Syst. Sci. 2005, 5, 345-355. [CrossRef] 
47. Ho, M.-C.; Shaw, D.; Lin, S.; Chiu, Y.-C. How Do Disaster Characteristics Influence Risk Perception? Risk Anal. 2008, 28, 635-643. [CrossRef] [PubMed]

48. Kung, Y.; Chen, S. Perception of Earthquake Risk in Taiwan: Effects of Gender and Past Earthquake Experience. Risk Anal. 2012, 32, 1535-1546. [CrossRef] [PubMed]

49. Enarson, E.; Phillips, B. Invitation to a new feminist disaster sociology: Integrating feminist theory and methods. In Women and Disasters: From Theory to Practice; Phillips, B., Morrow, B.H., Eds.; International Research Committee on Disasters: New York, NY, USA, 2008; pp. 41-74.

50. Donner, W.; Rodríguez, H. Population Composition, Migration and Inequality: The Influence of Demographic Changes on Disaster Risk and Vulnerability. Soc. Forces 2008, 87, 1089-1114. [CrossRef]

51. Donner, W.R. The Human Ecological Model and Its Application to Severe Weather Phenomena: Predicting Tornado Morbidity. Master's Thesis, University of Delaware, Newark, DE, USA, 2003.

52. Parkinson, D.; Zara, C. The hidden disaster: Domestic violence in the aftermath of natural disaster. Aust. J. Emerg. Manag. 2013, 28, 28-35.

53. Nyakundi, H.; Mogere, S.; Mwanzo, I.; Yitambe, A. Community perceptions and response to flood risks in Nyando District, Western Kenya. Jàmbá J. Disaster Risk Stud. 2010, 3, 346-366. [CrossRef]

54. Muttarak, R.; Pothisiri, W. The Role of Education on Disaster Preparedness: Case Study of 2012 Indian Ocean Earthquakes on Thailand's Andaman Coast. Ecol. Soc. 2013, 18, 51. [CrossRef]

55. Dragicevic, S.; Filipovic, D.; Kostadinov, S.; Ristic, R.; Novkovic, I.; Zivkovic, N.; Andjelkovic, G.; Abolmasov, B.; Secerov, V.; Djurdjic, S. Natural Hazard Assessment for Land-use Planning in Serbia. Int. J. Environ. Resour. 2011, 5, 371-380.

56. Petrović, A.M.; Dragićević, S.S.; Radić, B.P.; Milanović Pešić, A.Z. Historical torrential flood events in the Kolubara river basin. Nat. Hazards 2015, 79, 537-547. [CrossRef]

57. Ristić, R.; Kostadinov, S.; Radić, B.; Trivan, G.; Nikić, Z. Torrential Floods in Serbia-Man Made and natural hazards. In Proceedings of the 12th Congress INTERPRAEVENT 2012, Grenoble, France, 23-26 April 2012; pp. 771-779.

58. Petrović, A.; Kostadinov, S.; Dragićević, S. The inventory and characterization of torrential flood phenomenon in Serbia. Pol. J. Environ. Stud. 2014, 23, 823-830.

59. Dragićević, S.; Mészáros, M.; Djurdjić, S.; Drapavić, G.; Novković, I.; Tošić, R. Vulnerability of national parks to natural hazards in the Serbian Danube region. Pol. J. Environ. Stud. 2013, 22, 1053-1060.

60. ACAPS. Floods in Serbia and Bosnia and Herzegovina, and Croatia. Available online: https://www.acaps. org/sites/acaps/files/products/files/balkan_floods.pdf (accessed on 4 December 2018).

61. Tošić, I.; Unkašević, M.; Putniković, S. Extreme daily precipitation: The case of Serbia in 2014. Theor. Appl. Climatol. 2017, 128, 785-794. [CrossRef]

62. Cvetković, V. Fear and floods in Serbia: Citizens preparedness for responding to natural disaster. Matica Srp. J. Soc. Sci. 2016, 155, 303-324. [CrossRef]

63. Cvetković, V.M. The Impact of Age on Flood Preparedness in Serbia. Int. J. Hum. Soc. Sci. 2016, 6, 1-15.

64. Cvetković, V.; Dragićević, S.; Petrović, M.; Mijalković, S.; Jakovljević, V.; Gačić, J. Knowledge and Perception of Secondary School Students in Belgrade about Earthquakes as Natural Disasters. Pol. J. Environ. Stud. 2015, 24, 1553-1561. [CrossRef]

65. Paul, B.K.; Bhuiyan, R.H. Urban earthquake hazard: Perceived seismic risk and preparedness in Dhaka City, Bangladesh. Disasters 2010, 34, 337-359. [CrossRef]

66. Acimovic, L.; Beuk Pirusic, T.; Sabados, V. Country Study: Serbia. Available online: http:/ /om.ciheam.org/ om/pdf/b60/00800473.pdf (accessed on 4 December 2018).

67. Turner, R.H.; Nigg, J.M.; Paz, D.H. Waiting for Disaster: Earthquake Watch in California; University of California Press: Oakland, CA, USA, 1986; ISBN1 0520055500. ISBN2 9780520055506.

68. Mulilis, J.-P.; Lippa, R. Behavioral Change in Earthquake Preparedness Due to Negative Threat Appeals: A Test of Protection Motivation Theory. J. Appl. Soc. Psychol. 1990, 20, 619-638. [CrossRef]

69. Hurnen, F.; McClure, J. The effect of increased earthquake knowledge on perceived preventability of earthquake damage. Australas. J. Disaster Trauma Stud. 1997, 3, 1-14.

70. McClure, J.; Walkey, F.; Allen, M. When Earthquake Damage is Seen as Preventable: Attributions, Locus of Control and Attitudes to Risk. Appl. Psychol. 1999, 48, 239-256. [CrossRef]

71. Cohen, J. Statistical Power Analysis for the Behavioral Sciences; Academic Press: New York, NY, USA, 1988. 
72. Citizen Corps Personal Behavior Change Model for Disaster Preparedness; A Review of Citizen Preparedness Research; Community Preparedness Division, FEMA: Washington, DC, USA, 2006; Volume 4, pp. 1-13.

73. Ajzen, I.; Netemeyer, R.; Van Ryn, M. The Theory of Planned Behavior. Organ. Behav. Hum. Decis. Process. 1991, 50, 179-211. [CrossRef]

74. Gustafson, P.E. Gender differences in risk perception: Theoretical and methodological perspectives. Risk Anal. 1998, 18, 805-811. [CrossRef] [PubMed]

75. Lovekamp, W.E.; Arlikatti, S. Social Change and Empowerment. In Social Vulnerability to Disasters; Thomas, D.S., Phillips, B.D., Lovekamp, W.E., Fothergill, A., Eds.; CRC Press Taylor and Francis Group: Boca Raton, FL, USA, 2013; pp. 447-468.

76. Ahmad, N. Gender and Climate Change in Bangladesh the Role of Institutions in Reducing Gender Gaps in Adaptation Program. Social Development Paper. World Bank: Washington, DC, USA, 2012; Volume 126, pp. 1-26. Available online: http://documents.worldbank.org/curated/en/559391468340182699/pdf/ 678200NWP0P1250C0in0Bangladesh0web2.pdf (accessed on 4 December 2018).

77. Webb, J. Does Gender Responsive Disaster Risk Reduction Make a Difference When a Category 5 Cyclone Strikes? Care International: Vanuatu, 2017; pp. 1-56. Available online: https://www.care.org.au/wpcontent/uploads/2017/04/CARE (accessed on 4 December 2018).

78. United Nation Development Programme (UNDP). Gender and Disasters. 2010. Available online: http: / /www. undp.org/content/dam/undp/library/crisis\%20prevention/disaster/ (accessed on 4 December 2018).

(C) 2018 by the authors. Licensee MDPI, Basel, Switzerland. This article is an open access article distributed under the terms and conditions of the Creative Commons Attribution (CC BY) license (http://creativecommons.org/licenses/by/4.0/). 